DOI: http://dx.doi.org/10.4314//dd.v14i1.11

\title{
forum
}

Review article

\section{Get rights right in the interests of security of tenure}

\author{
ANNE POPE* \\ Senior Lecturer in Private Law, University of Cape Town
}

Review of Land, Power \& Custom: Controversies Generated by South Africa's Communal Land Rights Act, edited by Aninka Claassens \& Ben Cousins; ${ }^{1} \mathrm{xv}$ and pp 392 with accompanying DVD. Legal Resources Centre \& UCT Press, Cape Town, 2008. Soft cover; R295.00 ISBN: 978-1-91989-550-5.

\section{INTRODUCTION}

Land, Power \& Custom presents a very important commentary on indigenous land rights. Being a multi-disciplinary commentary, which is most welcome, it differs markedly from other writing on the topic. The basis for the commentary is to provide context to and evidence of the complexities generated by recent efforts that attempt to give effect to the constitutional mandate ${ }^{2}$ to secure tenure rights that are precarious for historical reasons

\footnotetext{
* Grateful thanks are due to my colleagues Professor Hanri Mostert (for her ongoing willingness to engage in vigorous debate with me about various topics, including aspects covered in the book under discussion) and Professor Chuma Himonga (for sharing her views and insights during our many discussions about customary law). Views expressed here are mine, as are any remaining errors.

${ }^{1}$ Hereafter referred to as Claassens \& Cousins.

${ }^{2}$ S 25(6), Constitution of the Republic of South Africa, 1996.
} 
and, simultaneously, to preserve the possibility of indigenous property management structures. That such dual efforts are required flows from both the mandate mentioned above as well as from section 39(3) of the Constitution which states that

"[t]he Bill of Rights does not deny the existence of any other rights or freedoms that are recognised or conferred by common law, customary law or legislation, to the extent that they are consistent with the Bill."

The commentary is largely a response to the Communal Land Rights Act ${ }^{3}$ and the Traditional Leadership and Governance Framework Act, ${ }^{4}$ collated in preparation for litigation that challenges the constitutionality of the former Act by alleging that it "undermines the rights of rural people to make them less secure than before". ${ }^{5}$ Judgment in Tongoane and others $v$ The National Minister for Agriculture and Land Affairs and others ${ }^{6}$ has since been delivered, its findings being mostly in favour of the applicants. I deal with the judgment later in this article.

The wording of section 25(6) of the Constitution is deceptively simple:

"a person or community whose tenure of land is legally insecure as a result of past racially discriminatory law or practices is entitled, to the extent provided by an Act of Parliament, either to tenure which is legally secure or to comparable redress."

The solution might seem obvious: enact legislation that secures tenure. Indeed, the White Paper issued by the Department of Land Affairs in 1997 boldly stated that a fundamental principle of tenure reform was that there should be a unitary system of land rights. ${ }^{7}$ But, as the various authors make clear in their contributions, there is nothing simple about the task of securing indigenous land rights. Instead, considerable complexity exists, some of it technical.

Other complexities concern political gamesmanship, ${ }^{8}$ power struggles at group or individual level, generally low levels of literacy in rural communities

${ }^{3}$ Act 11 of 2004; hereafter referred to as CLRA.

${ }^{4}$ Act 41 of 2003: hereafter referred to as TLGFA.

5 Claassens \& Cousins 3.

6 (11678/2006) [2009] ZAGPPHC $127 \quad$ (30 October 2009); available at http://www.saflii.org/za/cases/ZAGPPHC/2009/127.html.

7 White Paper on South African Land Policy (Department of Land Affairs, 1997) at 57-66.

8 Defined as "the art of winning games, or generally, of scoring points, by talk or conduct aimed at putting one's opponent off": Chambers Maxi Paperback Dictionary (1992) 427. 
and, importantly, no written record of the content of the particular customary laws and patterns from which to generate discussion about compatibility with constitutional principles. Significantly, furthermore, the content of existing indigenous land rights is very difficult to articulate in language, even in the vernacular. ${ }^{9}$ For example, it seems that there simply are no terms for "a wife's claim to an agricultural plot"; rather, the expectation that a wife should raise crops for the family seems to rest on the premise that she must have access to an agricultural plot. The expectation of access may not equate with a claim to a plot in the common law sense. The implication is that the expectation of access to land ought not to be taken as the equivalent of a claim to a real right in land. In turn, this technical difference has implications for registration of indigenous land rights.

The current deeds registration system depends strongly on the wellunderstood concept of real rights and, in principle, rights in land that do not meet the stringent requirements for recognition as real rights may not be registered..$^{10}$ Yet the CLRA seems to avoid interrogation of the possible content of "old order" rights and permits registration of "new order" rights. ${ }^{11}$ The definition of the latter does not shed any light on their content. The Act makes provision for a "Deed of Communal Land Right" which facilitates registration of a "new order" right. If a separate register is envisaged, then the political implications of entrenching land rights that are officially different should be carefully considered for fear of creating new perceptions of inferiority.

Indigenous land rights are not inferior to, just different from common law land rights. However, by definition, indigenous land rights are accorded to black people only. No other ethnic group is able to assert a claim to access to land on the same basis. Consequently, unless there is some way to prevent the perception that a separate register for indigenous land rights does not imply any sort of inferiority, it is easy to see how mischief could result from the existence of a separate register. Much political gain is currently sought from pointing out that the Deeds Registry statistics demonstrate a continuing skewed demographic profile of land ownership. If a separate register is envisaged for indigenous land rights, will these rights holders be counted in the same sum as other common law property right holders? Or will the

9 Personal communication, Professor TW Bennett, December 2009; see also Claassens \& Cousins 146.

${ }^{10}$ S 63(1) of the Deeds Registries Act 47 of 1937.

$11 \mathrm{~S} 5$ of the CLRA. 
skewing be institutionalised further to suit political ambitions? Too much is at stake, going into the future, for the importance of the "official face" of land rights to be carelessly disregarded.

These various aspects make for a volatile mix and the authors do well in their description and discussion of the information canvassed in the course of the research to demonstrate the flaws in the CLRA and the TLGFA. The flaws seem to arise from the drafters of the legislation either having ignored local voices who testify as to the actual customary practices or having failed to interrogate the content of customary law so as to explore the implications of registering a "right" that may not be a clear right in the common law sense but nevertheless must be secured. If overlapping or layered indigenous rights are registered and thus "fixed", as it were, the very nature of the indigenous land rights system is affected. Whether the implications are positive or negative is unknown for want of analysis.

This article provides an overview of the book under consideration. In so doing, it analyses and comments on particular difficulties and dilemmas in securing indigenous land rights. An analysis of the judgment that is the outcome of the legal challenge is followed by further reflection on particular issues. The discussion shows that, while the applicants in Tongoane can rightfully claim victory for succeeding in having several provisions of the CLRA declared unconstitutional, important questions remain unanswered. The implications of such omissions will need careful and thoughtful treatment by the Constitutional Court during the confirmation hearing at the beginning of March 2010.

In the next section the book is analysed, following the sequence of chapters.

\section{LAND, POWER \& CUSTOM ANALYSED}

In chapter one Ben Cousins gives a succinct flavour of the context in which the research was undertaken and lays the ground for the chapters that follow. He reiterates the principles that, according to the 1997 White Paper, ${ }^{12}$ should underlie tenure reform. There should be well-defined rights, including recognition of de facto rights, in a unitary system of land rights. Secondly, a choice of tenure system should be possible, provided there is consistency with the constitutional principles of democracy, equality and due process.

12 Department of Land Affairs (1997) 57-66. 
Several dilemmas emerge from consideration of these principles, including whether private ownership and its constituent elements should be the aim for all or whether the layered and overlapping rights of indigenous law can be accommodated and made secure. ${ }^{13}$ Central issues are how to determine the content of customary rights; how to prevent further homelessness if strong claims outweigh weak claims; how to ensure that tenure reform leads to social development. Cousins points out that the CLRA "combines elements of titling and recognition of customary tenure" but, in so doing, gives legitimacy to the "worst of both worlds". An individual will have a "secondary and poorly defined right to land, and ownership will vest in a large group ... represented by a structure ... that will exercise ownership on behalf of the group".14 The problem with this conceptualisation is that there are no mechanisms that ensure accountability to individual community members.

The basis of indigenous land rights is membership of a group and democratic decision-making and self-regulation. However, the legislative conceptualisation imposes a structure, apparently based on decentralised control but which is dependent on state appointment of traditional councils. This emulates apartheid-era thinking rather than facing the reality of indigenous land rights practices that depend strongly on localised decisionmaking and control. If land management and control are bureaucratic and politically motivated, there is little chance for rural people to be part of discussions and decision-making. And, if individual community members are unable to be heard, there is little hope for real social development; rather, the oppressive patterns of the past are likely to continue, leaving the poor and vulnerable no better off than before.

Henk Smith provides an overview of the CLRA in chapter two, which allows even those not well versed with the Act to understand the basis for the controversies and for the legal challenge. Broadly, the Act corporatises land administration, individualises communal rights, and decentralises public administration..$^{15}$ All state land under communal occupation, privately held communal land (e.g., registered in the name of a Communal Property Association ${ }^{16}$ ), as well as land designated by the Minister, fall to be dealt with

${ }^{13}$ Claassens \& Cousins $9 f f$.

${ }^{14}$ Claassens \& Cousins 15.

15 Claassens \& Cousins 39-40.

16 In terms of the Communal Property Associations Act 28 of 1996; hereafter referred to as CPA. 
in terms of this Act. The contradiction ought to be obvious immediately. How is it possible to bind private owners to follow the procedures of the Act?

Two institutions are created: a land rights board and a land administration committee. The former is envisaged as having a territorially larger jurisdiction than the latter. Each community is to have a land administration committee, which it should be possible to elect democratically. However, in terms of the TLGFA, traditional councils can be appointed and, if such a council exists, then this council has to be the land administration committee. In other words, the interaction of the two statutes can result in nullification of democratic processes in particular communities.

The Act envisages registration of indigenous land rights in the name of an individual, a group or a legal entity. "Communal land" is defined as land "at any time vested in a government contemplated in the Self-governing Territories Constitution Act". ${ }^{17}$ However, the Act does not take account of the situation where land is already owned or securely held by a group or an individual. For example, if the land owned by a CPA is located in an area that is otherwise managed and controlled on the basis of indigenous land law, there is a significant legal difference between the nature of the right registered in the name of the CPA and the rights included in possible Deeds of Communal Land Rights for other parts of the same geographical area. For individual community members, this legal difference may not be significant on a day-to-day basis but, from the point of view of outsiders, including local authorities, the CPA has ownership with its constituent entitlements and civic responsibilities, while the Deed of Communal Land Right confers something quite different. The legal differences could hold significant implications for local authorities that must levy rates and taxes as well as provide service delivery.

Chapter three explores whether the legislative process adopted during the genesis of the CLRA was appropriate. Christina Murray and Richard Stacey argue that Parliament did not adhere to the correct procedure and also did not involve the public appropriately in the passage of the Act. They discuss the differences between the procedures according to which a Bill must be "tagged" as it enters the legislative process. The tagging test is based on the Canadian "pith and substance" test ${ }^{18}$ and is used to decide whether the Bill under consideration falls under Schedule 4 of the Constitution. The significance of Schedule 4 is its listing of concurrent functions of the national and provincial

\footnotetext{
${ }^{17} \mathrm{~S} 2(1)$ (a) of the CLRA.

${ }^{18}$ Claassens \& Cousins 77.
} 
levels of government. In the case of concurrent provincial functions, the passage of a Bill should include a process of consultation with the provinces via the National Council of Provinces (NCOP) which serves to respect the integrity of the provinces. The authors point out that the CLRA

"marks a substantial shift away from the previous system in which the role of traditional leadership in the determination of access to and rights in land was based on customary practices. Not only is it a departure from a system in which decisions about land management and allocation were often taken by lower levels of social organisation, it is also a shift at an abstract level. The idea of absolute ownership endorsed by the Act is inconsistent with customary structures based on overlapping rights to land which survived at least partially into the $20^{\text {th }}$ century". 19

That such a radical change to indigenous land rights systems should be imposed without adequate and appropriate consultation seems contrary to constitutional expectations. The functional area of "indigenous law and customary law" is specifically a Schedule 4 competency. The authors argue that choosing to tag the Bill as section $75^{20}$ allowed Parliament to bypass engagement with the provinces. In turn, the NCOP was not given time to consult properly with local government or communities.

The nature of land rights in Africa is canvassed in chapter four, which is a fascinating and informative exposition by HWO Okoth-Ogendo. The author points out several "juridical fallacies"; ${ }^{21}$ for example, that indigenous law is not really law; that indigenous law does not confer property in land on individuals; and that indigenous social and governance institutions are not capable or suitable agents for allocating land, managing it and resolving disputes about land. These fallacies, mostly stemming from the colonial era, served to undermine and atrophy indigenous land governance systems. The consequent misrepresentation and distortion of indigenous land rights served the apartheid regime in its quest to construct its separation of black and white persons regarding ownership and use of land.

Okoth-Ogendo points out that the persistent tenure insecurity of indigenous law is not inherent to that system but, rather, is an inevitable and insidious consequence of the "dislocation of the indigenous systems from their social

\footnotetext{
${ }^{19}$ Claassens \& Cousins 83.

${ }^{20} \mathrm{~S} 75$ of the Constitution lays down a simplified legislative process for "Ordinary Bills not affecting provinces" - Editor.

${ }^{21}$ Claassens \& Cousins 96ff.
} 
and institutional context that defines and sustains them". ${ }^{22}$ He goes on to explain that indigenous land rights are not communal in nature; rather, the social order creates reciprocal rights and obligations that

"bind together and vest power in community members over land. It is the continuous performance of rights and obligations that determines who may have access to, or exercise control over, land and associated resources that specific communities occupy".23

The relevant insight is that access to land is a function of membership of a group and that the group is generally self-limiting rather than artificially created by a bureaucracy. Different levels of social organisation exercise specific functions of resource management and control. An understanding of this basic structure is key to the understanding that

"tenure under indigenous law is a complex process that relates access rights and functional equivalents to governance system at all levels of social organisation. Land tenure thus balances access rights, their functional equivalents and control". ${ }^{24}$

For these reasons, it is completely inappropriate to analyse indigenous land tenure in terms of "the conceptual categories of Anglo-European property law". ${ }^{25}$ The security of indigenous land rights is dependent on a working social organisation and structures that are able to carry out their functions in a sustainable manner. Yet the CLRA persists with the common view of indigenous rights: that there can be equivalence with real rights in land; that overlapping rights are not problematic; that separation of land rights from issues of social organisation is acceptable. This approach of the CLRA inevitably means that the State participates in "suppressing indigenous land rights and cultural resources", as a result of a "carry-over of colonial perceptions and because of a strong belief that indigenous land rights cannot support modern agrarian development". 26

The author argues strongly that the CLRA cannot achieve its stated objectives but, rather, will "undermine tenure security under indigenous land law". Amongst the reasons offered are that, while "communities" are defined

\footnotetext{
22 Claassens \& Cousins 98.

23 Claassens \& Cousins 100.

${ }^{24}$ Claassens \& Cousins 101.

25 Claassens \& Cousins 101.

26 Claassens \& Cousins 102.
} 
with reference to "shared rules determining access", there are no criteria by which to judge whether a community is a "community", nor what content the "shared rules" should display. Furthermore, the Minister's statutory power to prescribe "standard rules" makes the land administration system one of public administration rather than community-based. In addition, the use of concepts like ownership, beneficial occupation and freehold title in the context of indigenous land rights distorts the reality of the latter. In other words, the basis of indigenous land rights is changed to the extent that the self-regulating aspects of a well-functioning social organisation are undermined. The flexible and socially transformative character of indigenous land law becomes calcified and linked to the inevitably slow pace possible with legislative changes.

The character of "communal" tenure is explored further in chapter five, where Ben Cousins continues the theme of the difficulty of talking about indigenous land rights in the abstract. He uses ethnographic analyses and historical accounts to explain that land rights derive largely from recognised and accepted membership of a local group or community, usually on the basis of birth. The sustainability and continuity of the social units are dependent on access to land rights as well as basic conditions of human existence. The paradigm is one that accepts different forms of individual rights under community supervision together with common property rights (such as access to grazing, water, wood, etc).

Forced removals led to radical changes in the composition of rural communities, including overcrowding, which inevitably diminished tenure security, forcing overlapping of land rights which in the modern era leads to the conundrum of how to upgrade rights without causing negative effects on others' rights. ${ }^{27}$ Especially women's rights require attention, since the decision-making structures of the CLRA remain male-dominated. Furthermore, the importance of decision-making at local level, which is integral to indigenous land rights, must be acknowledged in reform efforts. ${ }^{28}$

In Cousins's view there is a poor fit between the CLRA and existing "communal" tenure insofar as the Act envisages a one-size-fits-all approach that transfers title to "communities" as juristic entities while individual members become holders of a Deed of Communal Land Right. How the nature and content of that right are to be indicated remains obscure. Furthermore, the nature and powers of the "community" as a juristic entity are not spelled out.

\footnotetext{
27 Claassens \& Cousins 115-118.

28 Claassens \& Cousins 126.
} 
For example, would the entity have contractual capacity? And legal capacity to sue and be sued?

Tom Bennett tackles the difference between "official" and "living" customary law in chapter six, pointing out that "the norms of written law strive towards precision and fixity, whereas the norms of custom are volatile and open-ended". ${ }^{29}$ The evolution of "official" customary law is premised on the need for certainty. However, it would be wrong to assume that indigenous law lacks certainty and coherence. Since "customary law derives from social practices considered to be obligatory by the communities in which they operate", it follows that "rules imposed by external authorities and rules having no local support cannot be considered valid". 30 Certainty and coherence are fostered by a sense of tradition which gives legitimacy to the rules.

The importance of appropriate terms of analysis, including terminology, is emphasised, as is the need for acknowledgement of the crucial role played by stable social organization. That the Constitutional Court has endorsed "living" customary law makes it clear that the constitutional protection of cultural diversity manifests when living customary law is seen to be valid, acceptable and protected and when it is grounded in current social practice. ${ }^{31}$ However, as can be seen in the case studies later in the book, establishing factual evidence to prove the existence of current social practice can be difficult, especially in circumstances where considerable power imbalances between rural villagers and their more urbanised and politically well-connected counterparts exist. ${ }^{32}$

In chapter seven Aninka Claassens and Sizani Ngubane discuss the interplay between land rights and power over land from women's point of view. They demonstrate clearly that statutory entrenchment and strengthening of traditional leaders inevitably increase the difficulties that women experience in gaining access to or in retaining land. Social facts like the decrease in the number of marriages mean that a system that does not include recognition of single women's entitlements to access and retain land has to be inherently unfairly discriminatory. In the view of these authors the CLRA reinforces the already distorted powers of traditional councils; it requires

\footnotetext{
${ }^{29}$ Claassens \& Cousins 139.

${ }^{30}$ Claassens \& Cousins 138.

31 Claassens \& Cousins 144.

32 Claassens \& Cousins 295ff.
} 
registration of individual rights in respect of family-held land; it ignores the reality of overlapping rights, disputed boundaries and current localised decision-making processes at different levels of society. In particular, the CLRA does not address the reality of unmarried women on family-held land. ${ }^{33}$

African holders of freehold title are not unknown in South Africa, contrary to much of the political propaganda. Some communities in the Eastern Cape have had freehold title for some 150 years because of historical peculiarities. Freehold title implies tenure security, but only when ownership is formally recorded in the Deeds Registry. ${ }^{34}$ In chapter eight Rosalie Kingwill presents an invaluable account of testimonies collected from two communities with freehold title, which shows the importance of the ethnographic approach in documenting knowledge, attitudes, practices and beliefs concerning titling. Both communities are located in the Grahamstown area, one being within the city limits. The significance of the location is that possible assumptions relying on the rural nature of a community must be tempered by factual evidence. The interviews revealed that titling is valued, especially because it makes those communities "different", and it serves somewhat to reinforce tenure security, certainly from an outsider's point of view. For example, the Deeds Registry entry provides protection against third parties as well as proof of ownership. But, titling being an alien concept, "freeholders adapted titling to their peculiar needs and continued to apply norms and practices based on customary principles of property management". 35

In the ideal situation this dual process would be unproblematic but, as Kingwill points out, the formal exclusion of other family members regarding decision-making that titling leads to can have severe consequences, especially for women and children. For example, if the husband were to alienate the property, which he is legally entitled to do if the property is registered in his name, the wife (or wives) and children would be hard-pressed to prevent it. The consequence of the alienation could be eviction and homelessness.

However, the expectation that title deeds would "encourage regular registration, thereby safeguarding ownership and the passage of property through legal transfers", has not manifested. ${ }^{36}$ Instead, the title deed itself

\footnotetext{
33 Claassens \& Cousins 175-178.

34 Claassens \& Cousins 184.

35 Claassens \& Cousins 185.

36 Claassens \& Cousins 193.
} 
symbolises ownership and, notwithstanding the fact that only one person's name appears on the deed, it

"project[s] a sense of shared family past and a common interest in the future, a fulcrum around which family ownership turns ... Title deeds represent a symbolic centre around which members define their relationship to the family and provide a link between the family and the outside world, as well as to the past". ${ }^{37}$

In other words, the property is regarded as a family asset rather than as a commodity that can be traded. The property may change hands several times within the extended family or between generations without involving the Deeds Registry. A disadvantage of this approach is that the official record may not reflect accurately who is responsible for paying, e.g., rates and taxes on the property, thus putting negative pressure on the local authority which must provide infrastructure and services.

Attitudes to ownership are illuminated clearly when exploring the practices associated with property succession. The idea that one person will be recorded as owner and will have powers to transact unilaterally is unacceptable. Instead, practice is based on the principle of negotiation which is focused on identifying the person who will be the "responsible person". In other words, the object is to find the right person to manage the property for the family for the next while:

"A responsible person is required to act in the interests of the entire family and does not have proprietary rights to exclude family members from the property: he or she is validated by family consent rather than by a title deed." 38

There is no common law equivalent to this role. Kingwill suggests that custodianship comes close. However, the common law notion of custodianship prevents the custodian from using the property for his or her own benefit; something that is clearly not intended in the indigenous context. Conceptually, ownership could be seen as burdened: on the one hand, the entitlement to alienate is restricted and, on the other, the "nominal" owner ${ }^{39}$ accepts positive obligations which include making decisions in the best interests of the family at large. This conceptualisation makes sense in light of the following:

The family concept of ownership is most aptly represented by the word "belonging". People belong to the extended family; property belongs to the whole family; and family members belong to the family land. Ownership functions to

\footnotetext{
37 Claassens \& Cousins 193.

38 Claassens \& Cousins 194.

39 "Nominal", because it is doubtful whether the change is recorded in the Deeds Registry.
} 
maintain family bonds, promote interaction and protect the family. It would be counter-intuitive to confer proprietary powers of alienation and control [on] defined individuals. ${ }^{40}$

A primarily historical perspective is used by Peter Delius in chapter nine to "identify critical patterns and processes of change" especially as far as the role of traditional leaders is concerned. ${ }^{41}$ The interactions between colonial powers and largely pre-literate societies in Africa led to a description and interpretation of indigenous land rights "in terms of Western legal constructs of property and ownership" 42 with which the colonialists were familiar. A combination of racism and nineteenth century social Darwinism "caricatured representation of African systems of land tenure which exaggerated the role of chiefs and diminished the rights of lower levels of political authority and households". 43 Furthermore, the colonial action of vesting ownership of the land in the state, and using traditional leaders as "state employees", gave them power and prestige to the detriment, in some cases, of individual communities and their members. In Delius's view, the implications of the CLRA include a fundamental shift in the location of ownership: instead of a system where ownership was vested in the state and control and management of the land lay with communities through the traditional leaders, an absolute form of ownership vested in a traditional council (which contradicts the character of overlapping rights at individual level) is envisaged. The proposed traditional council is able to exercise power without the old checks and balances that were inherent in the system.

Lungisile Ntzebeza describes the relationship between the African National Congress (ANC) and traditional authorities with reference to the processes that resulted in the CLRA and the TLGFA in chapter ten. The outcome of more than a decade of ambivalence and hesitation is that traditional authorities have regained powers from the ANC "on basically the same lines as its predecessor, the apartheid state". 44 In addition to political imperatives, global and continental trends in the broader political and economic context contributed to the political settlement conceded by the ANC. Although the Constitution guarantees the continued existence of the institution of traditional leaders,

\footnotetext{
40 Claassens \& Cousins 196.

${ }^{41}$ Claassens \& Cousins 211.

42 Claassens \& Cousins 213.

${ }^{43}$ Claassens \& Cousins 233.

${ }^{44}$ Claassens \& Cousins 238.
} 
their role and function are not clearly articulated, except to say that recognition of the institution applies only where not repugnant to the Constitution and other legislation. In line with constitutional principles, a visible bias towards elected local government is evident which obviously threatens the place of traditional authorities. In particular, the function of land allocation has caused considerable tensions in community structures. As Ntzebeza says:

"while rural residents enjoy the same citizenship rights as their urban counterparts in that they elect their councillors, on the vital issue of land allocation rural people become "subjects" in that decisions are taken by traditional councils dominated by unelected traditional authorities and their appointees". 45

Necessarily, this factual scenario "raises critical questions about citizenship and the nature of democracy in South Africa". 46

Chapters eleven, ${ }^{47}$ twelve ${ }^{48}$ and thirteen ${ }^{49}$ discuss and explain the case studies that form the basis for the legal challenge. Each of the four tells the story of a community that disputes, in different ways, the constitutionality of the CLRA on the basis that "while the Act purports to uphold 'custom and tradition', it in fact entrenches colonial and apartheid versions of chiefly power that undermine systems of land rights operating at layered levels of society". ${ }^{50}$ According to the Constitutional Court, indigenous tenure systems should not be scrutinised through a common law lens ${ }^{51}$ but, rather, the "living law" should inform the content of current customary law. However, in the case studies discussed in the following section - it is apparent that how to establish the content of living customary law is contested: disputes between chiefs and rural residents over which is the proper custom and which version is the "living law" form part of the legal challenge.

45 Claassens \& Cousins 258.

${ }^{46}$ Claassens \& Cousins 258.

${ }^{47}$ Authored by Aninka Claassens.

${ }^{48}$ Authored by Aninka Claassens and Durkje Gilfillan.

${ }^{49}$ Authored by Aninka Claassens with Moray Hathorn.

50 Claassens \& Cousins 262.

${ }^{51}$ Alexkor (Pty) Ltd \& another v Richtersveld Community \& others 2004 (5) SA 460 (CC); Bhe \& others v Magistrate Khayelitsha \& others 2005 (1) SA 580 (CC). 
Central to the challenge, therefore, is the content of indigenous land rights, as well as how "different levels of authority and decision-making within rural society articulate with one another in relation to land and how national policy and law affect this terrain of "local" interaction".52 Key issues are the appropriate level at which particular decisions about land rights should be taken, what process of decision-making accords with constitutional principles, and how to ensure appropriate accountability at different levels of decisionmaking. Quite clearly, tenure security is affected by control over land or lack thereof. In any system, whether one can assert a claim in respect of a land right is dependent upon whether institutions exist to enforce a successful claim. This means that the nature and scope of indigenous land rights as well as of chiefly power over land are crucial. Furthermore, the overarching question is how to articulate the meaning of customary law under the Constitution when establishing its content is still so nebulous, at least from an outsider's point of view.

In the final chapter Aninka Claassens draws the various threads of the contributions together to present an analysis and discussion that examine the central dilemma of how to recognize and support current patterns of use and occupation of land in communal areas without "fixing" unequal power relations and constructed notions of "customary" that cannot serve the end of promoting social development. ${ }^{53}$ Currently, many land rights transactions and arrangements occur "outside" or even against the law, which can have the consequence of legal vulnerability. They take place like this because of the friction between the "embedded reality of family ownership and the dominant legal paradigm of individual ownership". ${ }^{54}$ The stark difference between these two paradigms resides in the presence or absence of a timeless and neutral state of existence. The common law concept of ownership is regarded as essentially timeless and neutral, open to abstract theorising, whereas the indigenous family ownership notion embodies "contested and constructed versions of reality in which competing interests and forms of power are at stake". ${ }^{5}$ Nobody lives entirely in a "customary" or "modern" world. Instead they must manage an interface that is delicate and vulnerable to exploitation because of pressures like poverty, shortage of land, unemployment, the promise of riches from property developers, etc. In addition, those in positions

\footnotetext{
52 Claassens \& Cousins 263.

53 Claassens \& Cousins 355.

${ }^{54}$ Claassens \& Cousins 356.

${ }^{55}$ Claassens \& Cousins 356.
} 
of power may seek to retain such positions by favouring a view of customary law as an authoritarian and patriarchal political system. ${ }^{56}$

Clearly, how to ascertain the content of "living" law is a crucial element in the process of law reform. The distinction between law and customary practice must also be made. Acceptance of "living" law, which "by its very nature evolves as the people who live its norms change their patterns of life", 57 makes determination of the distinction extremely difficult, especially when the courts are looking for a closed system, ascertainable in law, rather than an open, evolving set of rules. ${ }^{58}$ As Claassens points out,

"problems and distortions arise in the application and interpretation of "processual" customary law in formalist courts. The differences in form (participation and discussion by a range of people as opposed to judges and magistrates presiding over a rigid process) and intent (finding a workable solution as opposed to applying fixed rules) mean that to determine the content of customary law by the standards of "formal" law is to apply a distorting paradigm." 59

While the formula (if there can be one) for ascertaining the content of indigenous land rights remains elusive, some guidance is given by Constitutional Court judgments. The pronouncement that customary law is "an integral part of South African Law, derives its validity from the Constitution and must be applied in accordance with the spirit, purport and objects of the bill of rights", is clear. 60 That customary law "must be interpreted to be "living customary law which is an acknowledgement of the rules that are adapted to fit in with changed circumstances" and not the codified version built on "colonial and apartheid precedents" is also clarified. ${ }^{61}$ What is not clear is how to manage the inevitable friction between a flexible system, on the one hand, and a strongly formalist system on the other.

"Formalist approaches that fail to perceive customary law as anything other than the rule-based application of law in court settings obscure the multiple voices

\footnotetext{
56 Claassens \& Cousins 357.

57 Alexkor Ltd \& another $v$ Richtersveld Community \& others 2004 (5) SA 460 (CC) par 52 per Langa CJ.

58 Claassens \& Cousins 361.

${ }^{59}$ Claassens \& Cousins 362 citing Alexkor at par 51.

60 Claassens \& Cousins 362.

61 Claassens \& Cousins 362 citing Bhe at par 87.
} 
that, in practice, contest and renegotiate the 'rules concerning property and authority on an ongoing basis'."62

To illustrate the difficulties that pervade analysis of the interface between indigenous land rights and common law property rights, I turn now to consider the judgment in Tongoane \& others $v$ Minister for Agriculture and Land Affairs \& others. $^{63}$

\section{TONGOANE \& OTHERS $v$ THE NATIONAL MINISTER FOR AGRICULTURE AND LAND AFFAIRS \& OTHERS}

As outlined above, four communities sought an order declaring sections of the CLRA and the TLGFA unconstitutional. The basis for the application included the assertions that land held in private ownership could not unilaterally be made subject to an imposed tribal authority's power, that long-standing arrangements regarding use of land should not be overridden unilaterally by abuse of tribal authority powers, and that the boundaries of tribal authority jurisdiction should not ignore the prior existence of separate communities. In each situation the issue is whether the parts of the CLRA and TLGFA that permit such conduct on the part of the tribal authorities can stand up to constitutional scrutiny. ${ }^{64}$

From the facts as described in the judgment, the Kalkfontein communities disputed the jurisdiction of the tribal authority over their land, given that they held it in private ownership despite the land falling within the area of the tribal authority. In addition, complaints of misconduct on the part of members of the tribal authority, including that of giving strangers access to the land of the Kalkfontein communities without the latter's permission or knowledge. In keeping with the previous dispensation, title to the land was held in the state's name but, as early as 1992, the communities had gone to considerable lengths to have title transferred to ensure their title and tenure would be secure. Despite court orders requiring transfer of title into the name of the communities, the efforts proved fruitless.

In the case of the Makuleke community, consequent to a forced removal the community's leadership was passed over when appointments to the tribal

62 Claassens \& Cousins 363.

$63(11678 / 2006)$ [2009] ZAGPPHC 127 (30 October 2009); available at http://www.saflii.org/za/cases/ZAGPPHC/2009/127.html.

64 The assertion that the incorrect parliamentary process was followed is not discussed here. 
authority were made, while abuses of power led to irregularities and interference with the community's management and control of the land to which they had been moved. Again, amongst other complaints, strangers were given grazing rights and were allocated sites under Makuleke control despite refusing to acknowledge Makuleke authority.

The Makgobistad community farmed land at Mayayane. Complaints about the conduct of the chief include that he condones abuse of power by his uncle who unilaterally changed the use of farm land to develop residential sites which he "sold" to strangers, permitted other structures to be built or developed on agricultural land without consultation or permission of the Makgobistad community.

The Dixie community manages and controls its land by vesting rights in the various families of the community in perpetuity. Grazing land, however, is used communally. A statutory tribal authority asserted that it has jurisdiction over Dixie and that the omission of the latter's land from the tribal authority's restitution claim was an error. The Dixie community disputes this as well as the claim that the tribal authority has jurisdiction over it, since it sees itself as an independent community.

In all four cases the issues might be described as facets of the same core problem: what happens when private ownership apparently clashes with indigenous land rights? Which system should prevail? Secondly, while it is logical that spatial boundaries are needed to indicate where jurisdictions begin and end, it is not logical or justifiable in a democratic society that previously existing independent communities should just be swallowed up by an imposed statutory authority.

Interestingly but disappointingly, the court in Tongoane does not undertake an analysis of these issues in reaching its finding that several sections of the CLRA are constitutionally unsound. Thus, while the applicants may be pleased to know that their private ownership rights are safe, it is not at all clear why private ownership is preferred. The restitution legislation permits the Land Claims Court to require that a CPA be established. But what did the legislature think would happen when a CPA is established in an area that might conceivably be subject to tribal authority jurisdiction? If customary law and common law have equivalent status under the Constitution, this does not mean that one ought never to be preferred over the other. It does mean, however, that when preference is to be given there should be a proper justification which itself stands up to constitutional scrutiny. The Tongoane judgment leaves us none the wiser. 
On the challenge that the incorrect parliamentary process was adopted in bringing the Act into being, the court was unmoved, stating merely that, in its view, no bad faith was involved in choosing the section 75 process. What does the presence or absence of bad faith have to do with whether Parliament chose the incorrect process? The challenge thus remains unanswered: did Parliament adopt the correct process?

\section{REFLECTIONS ON PARTICULAR ISSUES}

One of the technical difficulties raised by the CLRA is whether a statutory form of ownership, which requires registration in the Deeds Registry, can be summarily subjected to customary law at the unilateral behest of a traditional leader or by state endorsement. For example, restitution awards are sometimes conditional on the establishment of a CPA which becomes the registered owner of the land restored or awarded. In other words, statutory ownership is acquired by the CPA, a juristic entity. The members of the CPA may decide to manage and control the land in accordance with indigenous laws and practices but, from an outsider's point of view as well as officially, the CPA is the owner with all the constituent entitlements, responsibilities and obligations to neighbouring owners and the public at large. Yet, according to $\mathrm{s}$ 18 of the CLRA, the government can endorse the title deed to bring the registered ownership under the control of the "tribal authority".

No analysis or explanation is provided of why this anomalous treatment of ownership is justifiable. In effect, thus, section 18 means that CPA ownership in certain parts of the country can become an empty shell if someone in government so decides. In fact, as some of the case studies show, a tribal authority may unilaterally decide that it is in charge of the CPA. This cannot be constitutionally justifiable in light of recent Constitutional Court rulings on arbitrary deprivation. ${ }^{65}$ The mere existence of legislation does not make administrative action reasonable. As was outlined in First National Bank of SA Ltd t/a Wesbank $v$ Commissioner, South African Revenue Service; First National Bank of SA Ltd t/a Wesbank $v$ Minister of Finance, more is required, especially when ownership is to be materially and negatively affected. ${ }^{66}$

\footnotetext{
${ }^{65}$ See First National Bank of SA Ltd t/a Wesbank v Commissioner, South African Revenue Service, First National Bank of SA Ltd t/a Wesbank v Minister of Finance 2002 (4) SA 768 (CC); also referred to as FNB.
}

${ }^{66} \mathrm{FNB}$ at pars $100 \mathrm{ff}$. 
Regarding the need for spatial boundaries, it is axiomatic that the current deeds registration system and the enforcement of real rights depend on the surveying and subdivision of land into parcels, the conveyancing of land transfers and registration of ownership in a deeds registry. Such registration can be made only in the name of an individual or a juristic entity. The problem with a tribal authority as a juristic entity is that the autonomy of individuals is completely stifled. Ordinarily a juristic entity is created or joined voluntarily by its members. But if indigenous law structures are imposed, if localised decision-making regarding management and control of land is undermined, if accountability and integrity checks and balances are not implemented, then there is no democracy, no dignity or equality and certainly no freedom to move towards social and economic development.

Importantly, the point is emphatically not that indigenous law or its structures stifle autonomy or democratic possibilities; rather, it is that the very nature of indigenous law requires consultation, discussion and agreement. Imposition of structures that contradict and undermine these characteristics, especially relating to land, strikes at the heart of the system. In particular, as the authors are at pains to point out, the law should not be permitted to impose mechanisms that stifle "democratic possibilities inherent in the development of a living customary law that reflects all the voices currently engaged in negotiating transformative social change in rural areas". ${ }^{67}$

Secondly, unless contested boundaries are investigated and solutions found, "official" security of tenure will go nowhere in making security of tenure a factual reality for people who live in those areas. It is not in keeping with constitutional principles or with the spirit of ubuntu for someone in an office far away once again to draw lines on the map without consulting those who will be affected by where the line is drawn.

\section{CONCLUSION}

It may take time and thoughtful reflection to understand clearly why simply enacting legislation is probably the worst way to go about securing tenure. Security of tenure is about so much more. Integrity is all important, in those who manage and control land as well as in those who occupy or own it, or who make policy and law regarding land rights. Furthermore, it is unclear why the wealth of ethnographic, sociological, and historical information could not have

67 Claassens \& Cousins xiv-Xv. 
informed the law and policy makers. One of the great strengths of this book is the way it brings legal commentary together with ethnographic, historical and socio-economic information, thus enriching the accounts beyond the usual stark nature of legal analysis.

What bears thinking about is whether the principles outlined in the White Paper are not just too idealistic? Is it really possible to have a unitary system of land rights? Or to be able to choose freely which tenure system should apply? By what conceptual mechanism does a previously layered right turn into absolute ownership, as is envisaged in section 9 of the CLRA?

The use of concepts like ownership, beneficial occupation and freehold title in the CLRA is anomalous. It is obvious from the definition of "beneficial occupation" that it is cut and pasted from the Interim Protection of Informal Land Rights Act. ${ }^{68}$ If the basis of indigenous land rights is membership of a (family) group, why is it relevant whether a person has been there for five years? The distortion of indigenous land rights should be patent. Should use of these concepts persist, it should be repeated, the flexible and socially transformative character of indigenous land law will become calcified.

The paradigm of indigenous land rights, being based on membership of a group, is inherently inclusive of group members. Common law property rights, on the other hand, are inherently exclusive. The entitlements to prevent unwanted incursions into possession and to alienate clearly demonstrate this. It is thus completely anomalous to introduce concepts like beneficial occupation, ownership and freehold title in relation to indigenous land rights. It is also contradictory to convert "old order" rights into "new order" rights that emulate common law property rights. The paradigm shift from inclusivity in a layered system to exclusivity will destroy the very fabric of indigenous land rights.

On the other hand, the "living" nature of indigenous law must deal with the infrastructural needs for socio-economic development and upliftment. By definition, these needs must be concretised and cannot be nebulous. Land use planning does not admit of vague and nebulous strategies.

The complex and nuanced issues that arise in the context of harmonising indigenous land rights and private ownership are not easy to describe succinctly. This work is invaluable for anyone interested in the implementation of the constitutional mandate to secure tenure rights and in

${ }^{68}$ Act 31 of 1996. 
the interface between indigenous land rights and common law property rights. As is pointed out in the Acknowledgements, ${ }^{69}$ the courage and commitment of the four communities who were willing to take a stand at that interface contribute immeasurably to revealing what the interface entails as well as how to begin to address the ambiguities involved in securing indigenous land rights.

\section{BIBLIOGRAPHY}

\section{Books and other publications}

Claassens A. and Cousins B. (eds) Land, Power \& Custom: Controversies Generated by South Africa's Communal Land Rights Act (Legal Resources Centre \& UCT Press, 2008).

White Paper on South African Land Policy (Department of Land Affairs, 1997)

\section{Case law}

Alexkor (Pty) Ltd \& another $v$ Richtersveld Community \& others 2004 (5) SA 460 (CC).

Bhe \& others $v$ Magistrate Khayelitsha \& others 2005 (1) SA 580 (CC).

First National Bank of SA Ltd t/a Wesbank v Commissioner, South African Revenue Service, First National Bank of SA Ltd t/a Wesbank $v$ Minister of Finance 2002 (4) SA 768 (CC)

Tongoane and others $v$ The National Minister for Agriculture and Land Affairs and others (11678/2006) [2009] ZAGPPHC 127 (30 October 2009); available at http://www.saflii.org/za/cases/ZAGPPHC/2009/127.html.

\section{Legislation}

Communal Land Rights Act 11 of 2004.

Communal Property Associations Act 28 of 1996.

Constitution of the Republic of South Africa, 1996.

${ }^{69}$ Claassens \& Cousins X. 
Deeds Registries Act 47 of 1937.

Interim Protection of Informal Land Rights Act 31 of 1996.

Traditional Leadership and Governance Framework Act 41 of 2003. 